\title{
COMMENTS
}

\section{THE EMERGENT FEDERAL COMMON LAW \\ OF LABOR CONTRACTS: A SURVEY OF THE LAW UNDER SECTION 301}

Section 301 of the Taft-Hartley Act ${ }^{1}$ confers upon the district courts of the United States jurisdiction over "suits for violations of contracts" between employers and labor organizations without regard for diversity of citizenship. 2

The Supreme Court in Lincoln Mills, ${ }^{3}$ overcoming its earlier doubts concerning the constitutionality of the section, 4 upheld section 301 as a grant of federal power to regulate the enforcement of collective bargaining agreements. The Court ignored the legislative history which suggested that Congress merely intended to remove the common law impediments to bringing suit against labor unions. 5 Rather, the Court found in 301 a mandate to "fashion" from the national policy a federal law of the collective bargaining agreement. 6

The Court's decision caused immediate concern. ${ }^{7}$ One problem involved creating a wholely new federal common law of labor contracts, and determining the sources from which that law would be derived. Justice Douglas' opinion suggested that the express provisions of the National Labor Relations Act, the policies of that act, and compatible state law, all applied with judicial

129 U.S.C. $\$ 185$ (1958).

229 U.S.C. $\$ 301$ (a): "Suits for violation of contracts between an employer and a labor organization representing employees in an industry affecting commerce as defined in this chapter, or between any such labor organizations, may be brought in any district court of the United States having jurisdiction of the parties, without respect to the amounts in controversy or without regard to the citizenship of the parties."

3 Textile Workers Union v. Lincoln Mills, 353 U.S. 448 (1957).

4 See Association of Westinghouse Employees v. Westinghouse Elec. Corp., 348 U.S. 437 (1954) (Frankfurter, J.). For a summary of the constitutional issues involved, see Textile Workers Union v. American Thread Co., 113 F. Supp. 137 (D. Mass. 1953) (Wyzansky, J.).

5 See Meltzer, The Supreme Court, Congress, and State Jurisdiction over Labor Relations, Pt. II, 59 Colum. L. Rev. 269, 274 (1959), and materials cited therein.

6 In view of Justice Frankfurter's constitutional objections to section 301, this construction was probably required. It should be noted that there is little in the legislative history to support the Court's view, and that the Court itself carefully omitted references to this history in this part of the opinion.

7 See, e.g., Bickel \& Wellington, Legislative Purpose and the Judicial Process: The Lincoln Mills Case, 71 Harv. L. Rev. 1 (1957); Aaron, On First Looking intó the Lincoln Mills Decision, ARBitration and the LaW-Proceedings of the Twelfth ANNUAL MeEting NatIONAL ACADEMY of ARBITRATORS 1 (1959); Feinsinger, Enoforcement of Labor Agreements-A New Era in Collective Bargaining, 43 VA. L. REV, 1261 (1957). 
inventiveness, would supply the necessary rules of decision. Justice Frankfurter dissented, objecting that the majority imposed upon the federal courts "the task of applying a whole industrial code that is yet in the bosom of the judiciary."8 Allied with the problem of source for the new law is the translation of contract doctrines formulated in other areas of law into rules governing the collective agreement. The Court's language has suggested, at times, that the labor field presents problems so unique as to justify the creation of a specialized "industrial jurisprudence." 9 Critics have suggested, however, that the learning embodied in traditional contract doctrines provides persuasive analogies readily adaptable to the labor contract.10 Both problems, source and the emphasis to be placed upon traditional legal rules, are continuing themes underlying litigation under the section.

The purpose of this comment is to trace the development of federal rules of substantive law under section 301. The bulk of litigation under the section has centered around jurisdictional problems beyond the scope of this comment, with the doctrines of state-federal preemption, Board primary jurisdiction and judicial competence over contract actions creating a complex mosaic of competing forums.11 However, the judicial gloss placed upon the ability to bring suit under the section and the actions which will be entertained justifies treatment of these problems.

In litigation under section 301 the courts have construed the jurisdictional grant strictly. Suits between employers and labor organizations brought under the section must be based upon a contract between the parties.12 Both parties must meet the statutory definitions of employers or labor organizations under the National Labor Relations Act.13

8 Textile Workers Union v. Lincoln Mills, 353 U.S. 448, 465 (1957).

9 See note 130 infra and cases cited therein.

10 Cox, The Legal Nature of Collective Bargaining Agreements, 57 Mrch. L. Rev. 1, 14 (1957). Justice Frankfurter dissenting in Lewis v. Benedict Coal Co., 361 U.S. 459, 475 (1960), said in this connection: "There is no reason for jettisoning principles of fairness and justice that are as relevant to the law's attitude in the enforcement of collective bargaining agreements as they are to contracts dealing with other affairs, even giving due regard to the circumstances of industrial life and to the libretto that this furnishes in construing collective bargaining agreements."

11 For an analysis of the jurisdictional problems created by section 301, see Meltzer, supra note 5.

12 Aacon Contracting Co. v. Association of Catholic Trade Unionists, 178 F. Supp. 129 (E.D.N.Y. 1959); Sun Shipbuilding \& Dry-Dock Co. v. Marine Workers Union, 95 F. Supp. 50 (E.D. Pa. 1950) (inter-pleader to determine which of two unions entitled to check-off fund); Local 33, Hod Carriers Union v. Mason Tenders, 187 F. Supp. 737 (S.D.N.Y. 1960) (no jurisdiction to entertain declaratory judgment of rights in jurisdictional work dispute).

Suits between unions under section 301 present special problems, and the contractual requirement has been modified accordingly. See Comment, 69 YALE L. J. 299 (1959).

13 A. H. Bull Steamship Co. v. National Maritime Eng'rs Beneficial Ass'n, 250 F.2d 332 (2d Cir. 1957) (Supervisors' union). 
In Retail Clerks Int'l Ass'n v. Lion Dry Goods, Inc., ${ }^{14}$ the district court, applying the contract requirement, refused to entertain a suit based upon a strike settlement which in its view was not the type of contract enforceable under section 301. The settlement agreement provided for the restoration of the strikers to their jobs and authorized the union to engage in organizational activity upon the employer's premises. The company subsequently refused to permit the union to solicit in the company cafeteria during the lunch break, and transferred two of the strikers to new, but equivalent sales posts. The court's refusal to hear the union's suit for breach of the agreement may be explained upon technical grounds. Section 301 in terms applies to suits brought by unions "representing employees in an industry affecting commerce." The union in this case did not represent the employees either at the time of the strike or on the date of the agreement, although it had been the bargaining agent earlier.

Other courts have not construed the contract requirement so restrictively, and have entertained suits based upon strike settlement agreements. ${ }^{15}$ The language of section 301 does not expressly limit the type of agreement which is actionable to the "usual" collective bargaining agreement. In Lincoln Mills, the Supreme Court disregarded the legislative history which later persuaded the court in Retail Clerks. The Court's approach suggests that any contract between an employer and a labor union may be the basis of a 301 action. Section 301 is based upon the premise that responsibility in labormanagement relations is promoted by the enforcement of labor contracts. Moreover, the failure to enforce such agreements not only disrupts stable bargaining and working relationships, but also creates suspicion and distrust between the parties. These considerations persuasively urge that where there is a continuing relationship between the parties, all their agreements should be enforceable under section 301 .

These considerations may be inapplicable, however, where agreements with non-representative unions are involved. The act expresses a strong policy favoring the administration of the collective bargaining agreement by the majority union. Enforcement of agreements with non-majority unions may derogate from the authority of the bargaining agent and interfere with the bargaining agent's exclusive right to establish the terms and conditions of employment. The Retail Clerks case also suggests that the terms of such agreements may conflict with the Board's power to control the representation machinery by creating rights to engage in organizational activity inconsistent with the rights created by the act. These factors suggest that enforceability turns not upon the nature of the agreement, but upon the status of the parties to the agreement. Thus, all agreements with majority unions would be en-

14179 F. Supp. 564 (N.D. Ohio 1959).

15 Morgan Drive Away, Inc. v. Teamsters Union, 166 F. Supp. 885 (S.D. Ind. 1958), aff'd, 268 F.2d 871 (7th Cir. 1959); Textile Workers Union v. Arista Mills Co., 193 F.2d 529 (4th Cir. 1951). 
forceable; whereas agreements with minority unions would be unenforceable where the possibility of conflict exists with the rights and duties of a majority union. ${ }^{16}$ Where there is no majority union, as in Retail Clerks, the possibility of such conflict does not exist. In such cases there appears to be no basis for denying enforcement to agreements. The likelihood that a minority union may become the bargaining representative makes applicable all the arguments for enforcement based upon the psychological impact of breach on the parties' relationship.

A restrictive view of the agreements enforceable under section 301 was also taken by Judge Wyzanski in the Potter Press case. 17 There the court refused to enforce an arbitration agreement-a so-called legislative agreement in which the terms of the agreement are determined by the arbitrator-principally on the ground that the United States Arbitration Act did not allow the federal courts to enforce such agreements. Because the Supreme Court did not rely upon the Arbitration Act in Lincoln Mills, it may be inferred that there is no basis for distinguishing between grievance arbitration clauses and the broader clause involved in Potter Press. 18 The Court has largely resisted the Board's attempts to impose its judgment of the propriety of substantive terms upon the parties. ${ }^{19}$ This approval of freedom of contract seems contrary to the Potter Press approach and suggests that the scope of enforceable arbitration agreements is a matter to be determined through the bargaining process.

Tort claims are, of course, not cognizable under the section since no contract violation is involved.20 Stenzel \& Co. v. Department Store Union ${ }^{21}$ suggests, however, that actions for relief from tortious interference with contractual relationships may be joined with claims for breach of contract on the theory of pendant jurisdiction.

The district court entertained a suit for conspiracy to interfere with a business relationship where the complaint also alleged breach of the contract

16 But see Douds v. Local 1250, Retail Dep't Store Union, 173 F.2d 764 (2d Cir. 1949).

17 Boston Printing Pressman's Union v. Potter Press, 141 F. Supp. 553 (D. Mass. 1956), aff'd, 241 F.2d 787 (1st Cir. 1957), cert. denied, 355 U.S. 817 (1957).

18 Potter Press was followed by a recent district court case, Couch v. Prescolite Mfg. Corp., 191 F. Supp. 737 (W.D. Ark. 1961) (alternative ground), but at least one state case is contrary. Amalgamated Ass'n of Elec. Ry. Employees v. Pittsburgh Rys. Co., $393 \mathrm{~Pa}$. 219, 142 A.2d 734 (1958), cert denied, 358 U.S. 882 (1958) (enforcing an agreement to arbitrate amendments to retirement plan under the Pennsylvania Arbitration Act). See Meltzer, supra note 5, at 274 n.208.

19 See cases cited note 88 infra.

20 See note 12 supra.

2111 F.R.D. 362 (W.D. Mo. 1951). 
by one of the defendant unions. Although state law governed the tort claim, 22 the similarity of the issues involved in both the alleged contract breach and the tort made disposition of both claims in a single litigation preferable.

The courts have divided on whether declaratory judgment suits may be brought under section 301 and the Declaratory Judgments Act. The Declaratory Judgments Act confers jurisdiction to render declaratory relief where the court would otherwise have no jurisdiction over the case. ${ }^{23}$ Courts emphasizing the "violation" language of section 301 have refused to entertain such suits, reasoning that section 301 conferred jurisdiction only over contract violations. ${ }^{24} \mathrm{~A}$ fortiori, it is said, declaratory judgments may not be rendered since no violation of the agreement is involved. Other courts, following the lead of the First Circuit, have entertained such actions. 25 The lack of clarity in the legislative history undermines the technical construction given the section by courts denying declaratory relief, since the violation language, for all that appears, was largely fortuitous. Despite the mandate found in Lincoln Mills to create substantive law, Congress intended merely to make unions readily suable in the federal courts. There is no indication that Congress, had it considered the problem of declaratory relief, would have refused

22 In Sinclair Ref. Co. v. Atkinson, 48 L.R.R.M. 2045 (6th Cir. 1961), an employer brought an action for damages against the union for breach of a no-strike clause under section 301, and claims against the officers of the union for breach of contract and inducement of breach by their fellow employees. Jurisdiction under the second count was based upon diversity of citizenship. The trial court dismissed the second count against the individuals on the ground that section 301 barred personal liability for union officers. The Court of Appeals for the Sixth Circuit held that the court properly had jurisdiction over the claim against the individual defendants who were liable both for the damages resulting from their individual breach of their agreement not to strike, and for inducing breach by the other members of the union. This latter claim was, in the court's view, governed by state law. This result appears contrary to the provision in section 301(b) that only the union as an entity shall be responsible for damages arising out of breach of the collective bargaining agreement.

2328 U.S.C. \$2201 (1958).

24 Ferguson-Steere Motor Co. v. Teamsters Union, 223 F.2d 842 (5th Cir. 1955). $C f$. Mengel Co. v. Nashville Paper Prod. \& Specialty Workers Union, 221 F.2d 644 (6th Cir. 1955); Hall v. Sperry Gyroscope Co., 183 F. Supp. 891 (S.D.N.Y. 1960); Wamsutta Mills v. Pollock, 180 F. Supp. 826 (S.D.N.Y. 1959); International News Serv. v. Gereczy, 160 F. Supp. 5 (S.D.N.Y. 1958). These latter cases involved suits to stay arbitration and were held not cognizable since compliance with the contract was alleged.

25 The majority of courts directly faced with declaratory judgment suits have held that section 301 confers jurisdiction to entertain the action. In re Jacobson, 161 F. Supp. 222 (D. Mass. 1958), rev'd and remanded sub nom. Boston Mut. Life Ins. Co. v. Insurance Agents' Union, 258 F.2d 516 (1st Cir. 1958); New Bedford Defense Prods. Div. v. Local 1113, UAW, 160 F. Supp. 103 (D. Mass. 1958), aff'd, 258 F.2d 522 (1st Cir. 1958); Pittsburgh Rys. Co. v. Amalgamated Ass'n of Elec. Ry. Employees, 176 F. Supp. 16 (W.D. Pa. 1959); Modine Mfg. Co. v. Grand Lodge Int'l Ass'n of Machinists., 216 F.2d 326 (6th Cir. 1954); Weyerhaeuser Co. v. International Bhd. of Pulp Workers, 190 F. Supp. 196 (D. Me. 1960). 
to permit such suits to be entertained.26 Collective bargaining agreements are frequently amgibuous, and the rights of the parties unclear. Moreover, the formal parties to such agreements change, as, for example, when a signatory union is decertified, and another bargaining representative is selected by the employees. In such a case the rights of the parties are placed in doubt, and a judicial proceeding to determine the rights of the former parties and the incoming union would simplify the transition. 27 Because of the utility of the device and the apparent absence of a specific congressional purpose, suits for declaratory relief should be allowed.

A similar problem has arisen with regard to suits to stay arbitration. Under one view such suits are not predicated upon "violations" of the agreement because the moving party alleges compliance with the agreement.28 Here, too, a less technical approach to the language seems more appropriate since the federal courts are the proper forum for the litigation of collective bargaining disputes. Coupled with the rule that federal courts will not review the merits of arbitration awards, 29 refusal to entertain 30 or to permit removal ${ }^{31}$ of suits to stay arbitration in effect precludes the parties from securing a federal forum for the determination of their rights under the agreement. 32

${ }^{26}$ Cf. Prudential Ins. Co. v. Insurance Agents' Union, 169 F. Supp. 534 (S.D.N.Y. 1959). Judge Dimock suggests that the purpose of section 301 is to reduce industrial strife through the processes of judicial settlement and urges a liberal construction of section 301 . Accord, Local 28, IBEW v. Maryland Chapter, NECA, 48 L.R.R.M. 2031 (D. Md. 1961).

${ }^{27}$ See, e.g., Modine Mfg. Co. v. Grand Lodge Int'l Ass'n of Machinists, 176 F. Supp. 16 (W.D. Pa. 1959).

28 Hall v. Sperry Gyroscope Co., 183 F. Supp. 891 (S.D.N.Y. 1960); Wamsutta Mills v. Pollock, 180 F. Supp. 826 (S.D.N.Y. 1959); International News Serv. v. Gereczy, 160 F. Supp. 5 (S.D.N.Y. 1958). In Mengel Co. v. Nashville Paper Prod. \& Specialty Workers Union, 221 F.2d 644 (6th Cir. 1955), the suit was brought to declare an arbitration award invalid. The court refused to entertain the action since no contract violation was involved.

In Children's Dress Union, Local 91 v. Frankow Mfg. Co., 183 F. Supp. 671 (S.D.N.Y. 1960), the district court held that a suit filed in the state court to stay arbitration pursuant to the New York arbitration law was a suit within section 301 for purposes of removal. The case was remanded, however, because the removing union was the plaintiff in the action under New York law, and could not remove the action under section 1441. See also Minkoff v. Scranton Frocks, Inc. 172 F. Supp. 870 (S.D.N.Y. 1959) (action to enforce arbitration award held within the meaning of section 301); Minkoff v. Budget Dress Corp., $180 \mathrm{~F}$. Supp. 818 (S.D.N.Y. 1960). (Suit to enforce arbitration award remanded for untimely motion to remove.)

In Ingraham Co. v. Local 260, Radio \& Mach. Workers Union, 171 F. Supp. 102 (D. Conn. 1959) the district court allowed removal of an action to modify an arbitrator's award, indicating that in its opinion either party to an arbitration award could properly remove the action from a state court.

29 See infra at p. 731.

30 See note 28 supra.

31 Ibid.

32 This problem will be especially acute if state law is not superseded by federal law in suits brought in the state courts. See generally Meltzer, supra note 5, for a review of the conflicting policies involved in federal-state preemption in this area. 
It has been widely held that individuals may neither sue nor be sued under section 301.33 The language of the section does not compel this result. The phrase, "between an employer and a labor organization," may be read to modify either "suits" or "contracts." Although either construction is plausible on the face of the statute, the courts have read the language to modify "suits" and have concluded that individuals lack standing under the section. This result is justifiable on policy grounds and is consistent with the statute read as a whole. Permitting individuals to bring actions under section 301 would impair the union's right to administer the agreement. Moreover, the express authorization in section 301(b) for unions to sue "in behalf of the employees" implies that the union is the proper party to bring 301 actions. In view of the purpose manifest in the legislative history to make unions, as entities, responsible for their contracts, the courts' construction appears reasonable. Absent standing by individual members, only unions as entities may sue under 301 , and a class action on behalf of the members of the union does not create jurisdiction. ${ }^{34}$

Problems of the employers' standing to sue have centered around situations in which the collective bargaining agreement was entered into by an employers' association. Two courts have permitted individual employers to sue on contracts entered into on their behalf by the association, 35 and a third court has permitted the association to bring the action itself. ${ }^{36}$ According to the law of agency, a contracting association is either an agent acting on behalf of the individual employers or is itself a principal. Logically, these legal relationships are mutually exclusive; either an individual employer or the association has the right to bring a 301 action, but not both. Although the three cases can be reconciled on their facts under either theory, agency law itself seems inapplicable. Voluntary selection of a multi-employer bargaining unit, which reflects custom or the practical necessities of bargaining in a particular industry, should not affect the capacity to sue under section 301 . Either individual employers or the association should be considered real parties in interest for purposes of suit, and the selection of the plaintiff should be left to the discretion of the parties.

${ }^{33}$ Morgan Drive Away, Inc. v. Teamsters Union, 166 F. Supp. 885 (S.D.Ind. 1958), aff'd, 268 F.2d 817 (7th Cir. 1959); Rock Drilling Union v. Mason \& Hanger Co., 217 F.2d 687 (2d Cir. 1954); Sinclair Ref. Co, v. Atkinson, 187 F. Supp. 225 (N.D. Ind. 1960); Burlesque Artists Ass'n v. Hirst Enterprises, 134 F. Supp. 203 (E.D. Pa. 1955).

${ }^{34}$ Schatte v. International Alliance, 84 F. Supp. 669 (S.D. Cal. 1949), aff'd, 182 F.2d 158 (9th Cir. 1950).

35 Teamsters Union v. Morrison-Knudsen Co., 270 F.2d 530 (9th Cir. 1959); Farina Bros. Co. v. United Bhd. of Carpenters, 152 F. Supp. 423 (D. Mass. 1957).

${ }^{36}$ Employing Plasterer's Ass'n v. Operative Plasterers Ass'n, 172 F. Supp. 337 (N.D. III. 1959). The Farina Brothers case, supra note 35, suggests in dicta that only the employer individually may sue, on the theory that the association is merely an agent in signing the agreement. 
One court has refused to permit individual employer members of an association to bring suit by analogy to the inability of individual union members to maintain a 301 action. 37 The disability of individual union members to bring such actions reflects policy choices favoring administration of the collective bargaining agreement by the bargaining representative. The enterprise interests in multi-employer bargaining units present markedly different problems, and since contract violations may affect only a single employer, the relationships are not apposite.

Closely related to the question of standing to sue is the problem raised by the distinction made in Association of Westinghouse Employees v. Westinghouse Elec. Corp. 38 between breaches of contract involving "uniquely personal rights" which are actionable only by individual employees, and violations affecting the union qua union. Westinghouse involved a suit by the union for wages allegedly due under the agreement. The Court of Appeals for the Third Circuit, adopting an "eclectic" theory of the collective bargaining agreement, held that promises to pay wages ran only to the individual employees and could not be enforced by the union under section 301. Mr. Justice Frankfurter, speaking for only three members of the Court, 39 rejected the Third Circuit's original approach to the problem, but reached the same result on the ground that Congress did not intend to make individual wage claims actionable under 301.

The Westinghouse distinction between individual claims under the collective bargaining agreement and union claims has been applied by numerous lower federal courts to deny jurisdiction under section 301.40 In the Pullman Standard

37 Ketcher v. Sheet Metal Workers' Ass'n, 115 F. Supp. 802 (E.D. Ark. 1953).

38210 F.2d 623 (3d Cir. 1954); aff'd on other grounds, 348 U.S. 437 (1955). The courts have always experienced difficulty in framing a legal theory adequately explaining the legal relations created by tripartite transactions. The collective bargaining agreement-involving as is does rights and duties of employers, employees, and the union as an entity-is no exception. The Court of Appeals was attempting to avoid the difficulty of framing a unitary theory of the collective bargaining agreement by fragmenting the promises exchanged according to the party they affected. Regrettably, as Mr. Justice Frankfurter pointed out, the complex relationships created between employer, employees and the union do not admit of such a simple resolution. See, Cox, supra note 10 . For a brief history of the legal theories applied to such agreements see Jaeger, Collective Labor Agreements and the Third Party Beneficiary, 1 B.C. IND. \& CoM. L. Rev. 125 (1960).

39 Mr. Justice Frankfurter wrote for himself and Justices Burton and Minton. The Chief Justice, joined by Mr. Justice Clark, concurred in the result. In dissent, Justices Douglas and Black presaged the Court's later decision in Lincoln Mills by arguing that section 301 was a grant of power to create federal rules of substantive law. The "uniquely personal rights" language is from the Chief Justice's concurring opinion.

40 United Steelworkers v. Pullman Standard Car Mfg. Co., 241 F.2d 547 (3d Cir. 1957) (reduction of pension by amount of workman's compensation award); Radio \& Mach. Workers Union v. General Elec. Co., 231 F.2d 259 (D.C. Cir. 1956) (discharge without notice); Textile Workers Union v. Williamsport Textile Corp., 136 F. Supp. 407 (M.D. Pa. 1955) (vacation pay); Textile Workers Union v. Bates Mfg. Co., 158 F. Supp. 410 (D. Me. 1958) (mandatory retirement); Local 180, UAW v. J.I. Case Co., 185 F. Supp. 130 
Car case, 41 the leading court of appeals decision on the point, Judge Hastie's opinion suggests that a union bringing an action under 301 must bear the burden of demonstrating its institutional interest in the claim. This view was sharply rejected in Local 90 , Stove Mounters Union v. Welbilt Corp. ${ }^{42}$ where the district court entertained a suit to compel payments into a pension fund. The court there read Westinghouse as eliminating only individual claims for wages from 301, and not as establishing in all cases a burden requiring the union to show its interest.

The issue may have been settled sub silentio by the Supreme Court in the United Steelworkers v. Enterprise Wheel \& Car Corp. 43 decision. Without discussion of the Westinghouse case, the Court affirmed the judgment of the lower court ordering arbitration of a discharge allegedly in violation of the agreement. It is difficult to conceive of a matter more uniquely personal to an individual employee than his discharge, and, since the decision contemplated the possibility of an arbitrator's award of reinstatement, the decision may be read as removing the vitality from Westinghouse. The decision was so read by the Court of Appeals for the Fifth Circuit in Mississippi Valley Elec. Co. v. Local $130, I B E W, 44$ where the court upon rehearing reversed its

(E.D. Wis. 1960) (vacation pay); Local 2040, Int'l Ass'n of Machinists v. Servel, Inc., 268 F.2d 692 (7th Cir. 1959) (damages for discontinuance of plant operations); Kosley v. Goldblatt Bros., Inc., 251 F.2d 558 (7th Cir. 1958) (jurisdiction based on diversityarbitrability of claim for wages); ILGWU v. Jay-Ann Co., 228 F.2d 632 (5th Cir. 1956) (pension and welfare fund payments); Communications Workers v. Ohio Bell Tel. Co., $160 \mathrm{~F}$. Supp. 822 (N.D. Ohio 1958) (strike time benefit and vacation pay credit), aff' $d, 265$ F.2d 221 (6th Cir. 1959); Garfield Local 13-556, Oil Workers Union v. Heyden Newport Chem. Corp. 172 F. Supp. 230 (D.N.J. 1959) (suit to enjoin payment of pension fund after change in funding reserve). Contra, United Constr. Workers v. Electro Chem. Engraving Co., 175 F. Supp. 54 (S.D.N.Y. 1959) (welfare and pension payments); Local 90, Stove Mounters Union v. Welbilt Corp., 178 F. Supp. 408 (E.D. Mich. 1959) (pension fund payments).

Assignment of individual claims to the union will not avoid the Westinghouse rule. Silverton v. Valley Transit Cement Co., 249 F.2d 409 (9th Cir. 1957).

41 United Steelworkers v. Pullman-Standard Car Mfg. Co., supra note 40, at 552. Judge Hastie implies that only suits involving the union's responsibilities as bargaining agent may be brought under section 301 .

42178 F. Supp. 408 (E. D. Mich. 1959).

43363 U.S. 593 (1960). In suits brought to compel arbitration of claims that arguably are within the ambit of the Westinghouse rule, or to enforce arbitration awards with benefits running to individual employees, the courts have not applied the Westinghouse rule meticulously. See American Brake Shoe Co. v. Local 149, UAW, 285 F.2d 869 (4th Cir. 1961) (arbitration award of retroactive reclassification of work assignment); A. L. Kornman Co. v. Amalgamated Clothing Workers, 264 F.2d 733 (6th Cir. 1959) (enforcement of vacation pay award); Item Co. v. New Orleans Newspaper Guild, 256 F.2d 855 (5th Cir. 1958) (arbitration of individual discharge); Tool \& Die Makers Union v. General Elec. Co. X-Ray Dept., 170 F. Supp. 945 (E.D. Wis. 1959) (seniority provisions); Textile Workers Union v. Cone Mills Corp., 268 F.2d 920 (4th Cir. 1959), reversing 166 F. Supp. 654 (M.D.N.C. 1958). But see United Steelworkers v. New Park Mining Co., 169 F. Supp. 107 (D. Utah 1958), aff'd, 273 F.2d 352 (10th Cir. 1959).

44285 F.2d 229 (5th Cir. 1960). The district court noted the retreat from Westinghouse in Lincoln Mills and granted enforcement to an arbitration award of money damages for 
earlier decision denying enforcement of an arbitration award granting individual employees monetary damages for improper application of the contract wage rate. In its view Westinghouse is now overruled.

It is perhaps surprising that the Westinghouse approach was so favorably received by the lower courts. Section 301(b) expressly states that a union may sue "in behalf of the employees whom it represents." 45 Moreover, Mr. Justice Frankfurter's critical analysis of the Third Circuit's theory in Westinghouse pointed out the difficulty of distinguishing the terms of an agreement which benefit the union as an institution from terms which benefit only individual employees. As applied in the cases, however, the Westinghouse distinction requires just this analysis, since the determination that the union lacks a sufficient interest to bring suit necessarily is a finding that the interest involved is personal to the individual employees. The critical weakness in thin distinction is the assumed mutual exclusiveness of union and individual employee interests. The Westinghouse approach ignores the factual community of interest between the union and its members, as well as the union's abiding interest as the administrator of the agreement in the enforcement of all its substantive terms. 46

These interests have been most frequently recognized in cases involving the enforcement of arbitration awards, where many courts have disregarded the nature of the underlying claim for jurisdictional purposes. The policy of section 301 to promote the development of contractual responsibility in labor relations suggests that Westinghouse be considered overruled. At best the case was a holding action by those members of the Court convinced that the grant of jurisdiction was unconstitutional. At worst it prevents enforcement, as a practical matter, of individual claims under the contract which are too small to justify individual suit, but which in terms of the aggregate employee interest are significant. Enforcement of such claims by the union either in arbitration or direct suit seems most consistent with the language of the section and the duties of the bargaining agent under the act.

\section{II}

Hampered by preoccupation with questions of jurisdiction and procedure, the courts have been slow to develop substantive rules of labor contract law. The pervasiveness of arbitration is also a retarding factor. Much of the litigation under the section has been to compel private settlement of disputes

individual employees. 175 F. Supp. 312 (E.D. La. 1959). The Court of Appeals for the Fifth Circuit reversed. 278 F.2d 764 (5th Cir. 1960). On rehearing, after the Supreme Court decision in Enterprise came down, the court reversed itself, per curiam, one judge dissenting.

45 "Any such labor organization may sue or be sued as an entity and in behalf of the employees whom it represents in the courts of the United States." Section 301 (b). 29 U.S.C. $\$ 185$ (1958).

$46 C f$. Cox, supra note 10 , at 6. 
in the arbitration forum. Nevertheless, substantive rules have begun to emerge in some areas.

\section{Principles of CONTRACT CONSTRUCTION}

The courts have looked to the past practice of the parties ${ }^{47}$ and the history of bargaining between them ${ }^{48}$ in determining the meaning of the collective bargaining agreement. The courts' practice in this regard is not inconsistent with their approach to commercial contracts, but suggests possible conflict with the parol evidence rule. Although it involved the enforcement of a Board unfair labor practice order, the Boone County case ${ }^{49}$ is perhaps typical. The Board found that the union had violated the $8(\mathrm{~b})(3)$ duty to bargain by engaging in an unprotected strike in violation of the agreement. Typically, the problem of technological unemployment in the coal industry has been alleviated by retraining miners to operate newer equipment. In Boone County a new job superintendent brought in two outsiders to operate loading equipment and the union struck. Although the agreement did not contain an express no-strike clause, the Board construed the grievance provision, which provided for the submission of all grievances to arbitration, as implying a no-strike clause. The Board, extending its analogue of procedural due process in the bargaining area, held that this amounted to unilateral action changing the agreement and, therefore, a violation of section 8(b)(3).50 The Court of Appeals for the District of Columbia, expressing doubt that the union's action violated the statute, refused enforcement of the Board's order on the ground that the rejection of an express no-strike clause during the contract negotiations made the arbitration clause a "gentlemen's agreement." In short, the court rejected the Board's not unreasonable construction of the language of the agreement by reference to the parties' conduct during bargaining.

47 American Stores Co. v. Johnston, 171 F. Supp. 275 (S.D.N.Y. 1959) (retirement age). But see Garmeada Coal Co. v. UMW, 230 F.2d 945 (6th Cir. 1956) (lax enforcement of contract right not a waiver of an express contract term).

${ }^{48}$ Maryland Tel. Union v. Chesapeake \& Potomac Tel. Co., 187 F. Supp. 101 (D. Md. 1960) (pregnancy leaves and job reinstatement); Local 937, UAW v. Royal Typewriter Co., 88 F. Supp. 669 (D. Conn. 1949); Bakery Workers v. National Biscuit Co., 177 F.2d 684 (3d Cir. 1949) (compulsory retirement); Independent Petroleum Workers v. Standard Oil Co., 275 F.2d 706 (7th Cir. 1960) (arbitration of sub-contracting).

49 UMW v. NLRB, 257 F.2d 211 (D.C. Cir. 1958). Followed in Mile Branch Coal Co. v. UMW, 286 F.2d 822 (D.C. Cir. 1961) (suit for damages for breach of no-strike clause).

50 Arguably the resort to economic pressure is a unilateral attempt to modify the agreement, since a strike circumvents the contractual mechanism, the grievance procedure, for dealing with disputes. This approach to union action is closely related to the Board's doctrine of employer bad faith demonstrated by such unilateral action under section 8(a)(5). But see NLRB v. Katz, 47 L.R.R.M. 2967 (2d Cir. 1961). For a discussion of the unfair labor practice aspects of Boone County, see ABA, Commitre on DeVELOPMENT OF THE LAW UNDER THE NATIONAL LABOR RELATIONS ACT 71, 72 (1959) [hereinafter cited as ABA REP.]. 
Two recent Supreme Court decisions cast doubt upon the propriety of reliance upon the history of negotiations and prior agreements in construing collective bargaining agreements. In Lewis v. Benedict Coal Corp., 51 a case involving the same national coal agreement litigated in Boone County, an equallydivided Court affirmed the Sixth Circuit's implication of a no-strike clause.

Perhaps more significant was the Court's refusal in United Steelworkers v. Warrior \& Gulf Nav. Co.52 to consider the rejection, during bargaining, of union demands for limitations upon the company's right to sub-contract. The Court refused to consider this history as relevant to the scope of a management prerogative clause, asserted as a defense to union demands for arbitration of a dispute concerning sub-contracting. The Warrior approach was followed by a recent district court case where arbitration was ordered over the employer's objection that union demands for severance pay had been withdrawn during negotiations. 53 However, in Local 725, Operating Eng'rs Union v. Standard Oil Co.,54 the district court distinguished Warrior as involving a vague management prerogative clause, and held a sub-contracting dispute non-arbitrable where union proposals for limitations upon subcontracting had been consistently rejected.

Little reliance can be placed on Benedict or Warrior in view of the special circumstances under which they were decided. Benedict, of course, was decided by an equally-divided Court and has no precedent value. Warrior was an arbitration case, and the Court's decision may have rested wholly upon the favored position of arbitration as a means of settling labor disputes.55

Several courts have applied the parol evidence rule to collective bargaining agreements. 56 In Local 600, UAW v. Ford Motor Co.,57 although it did not rely upon the parol evidence rule, the court refused to give credence to the

51362 U.S. 459 (1960).

52363 U.S. 475 (1960).

s3 United Saw Workers v. Porter Co., 190 F. Supp. 407 (E.D. Pa. 1960). Accord, Association of Westinghouse Salaried Employees v. Westinghouse Elec. Corp., 283 F.2d 93 (3d Cir. 1960).

54186 F. Supp. 895 (D.N.D. 1960). Compare Maryland Tel. Union v. Chesapeake \& Potomac Tel. Co., 187 F. Supp. 101 (D. Md. 1960), where the court ordered arbitration of pregnancy leaves and job reinstatement, but found it "hard to believe that the Court means the positions taken and abandoned during collective bargaining can never be considered ... especially where a demand is withdrawn as the result of an agreement between the parties." Id. at 108-09.

55 The refusal of the courts to consider such evidence in arbitrability proceedings does not, of course, mean that it is irrelevant. The arbitrator may, and usually does, consider such evidence in deciding the merits of grievances. The Court's views in Warrior probably should be considered as establishing arbitration as the proper forum for such arguments.

56 Teamsters Union v. Morrison-Knudsen Co., 270 F.2d 530 (9th Cir. 1959); Local 600, UAW v. Ford Motor Co., 113 F. Supp. 834 (E.D. Mich. 1953). See also Communications Workers v. Ohio Bell Tel. Co., 160 F. Supp. 822 (N.D. Ohio 1958), aff'd mem., 265 F.2d 221 (6th Cir. 1959) (partial performance of a written contract excludes proof of an oral agreement subsequently made).

57113 F. Supp. 834 (E.D. Mich. 1953). 
union's assertion that a lengthy and detailed agreement contained an implied term not to decentralize plant operations. The parol evidence rule was explicitly applied in Local 839, Teamsters Union v. Morrison-Knudsen Co.58 to exclude union evidence that the atomic energy installations at Hanford, Washington, were excluded from a collective bargaining agreement prescribing the terms and conditions of employment in Benton County where Hanford was located. In Lewis $v$. Mears, 59 however, a coal mine operator was permitted to testify that the agreement was not to become effective until he received a signed copy from the union and that he had never received a copy, under the exception to the parol evidence rule which allows the reception of oral testimony to prove that no agreement was reached. The Mears court concluded that "the federal courts in fashioning a "body of federal law in the light of the national labor policy' have simply adopted and applied the common law parol evidence rule."60 The approach of the Boone County court belies this statement of the federal rule. It should be noted, however, that Boone County did not involve the parol evidence rule and is, moreover, justifiable under the exception to the parol evidence rule admitting evidence to clarify the meaning of ambiguous contract terms. Since Warrior involved the arbitrability of a dispute and the arbitration forum does not generally follow strict rules regarding the admission of evidence, the degree of strictness with which the parol evidence rule will be applied to section 301 contracts must be considered an open question.

The courts have not imposed statute of frauds requirements upon collective bargaining agreements litigated under section 301.61 However, where the parties themselves stipulate that only written agreements will be enforceable, even a statute of frauds memorandum is insufficient. 62

Only one case has dealt with the problem of incorporation by reference of extrinsic material into the collective bargaining agreement. In $A F L v$. Western Union Tel. Co., ${ }^{63}$ the union brought suit claiming that one of its 58270 F.2d 530 (9th Cir. 1959).

59189 F. Supp. 503 (W.D. Pa. 1960). See also Lewis v. Toth, 280 F.2d 422 (3d Cir. 1960); Lewis v. Mears, 168 F. Supp. 134 (N.D. W. Va. 1958), aff'd, 268 F.2d 427 (4th Cir. 1959). These decisions were distinguished in the principal case as varying the terms of the written agreement. It is a doubtful distinction on the facts.

60 Id. at 506.

61 Burlesque Artists Ass'n v. Hirst Enterprises, 267 F.2d 414 (3d Cir. 1959) (oral modification of written agreement); United Shoe Workers v. Le Danne Footwear, Inc. $83 \mathrm{~F}$. Supp. 714 (D. Mass. 1949). But see Hamilton Foundry \& Mach. Co. v. International Mach. Workers, 193 F.2d 209 (6th Cir. 1951) (dictum to the effect that Ohio Statute of Frauds applies to section 301 contracts).

62 Local 201, Radio \& Mach. Workers Union v. General Elec. Co., 283 F.2d 147 (1st Cir. 1960).

63 AFL v. Western Union Tel. Co., 179 F.2d 535 (6th Cir. 1950). Where supplemental agreements are contemplated, but not made, the situation is treated as if no contract existed as to those points. Local 201, Radio \& Machine Workers Union v. General Elec. Co., 163 F. Supp. 741 (D. Mass. 1958) (arbitration not ordered). 
members was entitled to a pension under the terms of the agreement. Although the agreement did not expressly include a detailed statement of the pension program, article 34 stated that the company undertook not to abandon or modify the program during the life of the agreement. The court of appeals reversed the district court's dismissal of the claim, holding that the company pension program was part of the agreement between the parties. Collective bargaining agreements are often informally created and frequently involve local variations upon master national settlements. A flexible approach to the problem of incorporation by reference is consistent with the practicalities of settlement and facilitates the drafting of concise agreements.

In construing collective bargaining agreements the courts have resorted to implied terms where necessary to avoid harsh results dictated by the bare language of the agreement. In Local 4264, United Steelworkers v. New Park Mining Co., ${ }^{64}$ the Tenth Circuit relied upon an implied covenant of good faith on the part of the employer not to alter his mining operations in order to avoid his contractual obligations to the union. The union had brought suit for breach of the agreement and a declaration of rights after the employer unilaterally ceased his own mining operation and entered into a leasing arrangement with some of the employees to operate the property. Remanding for reconsideration of the good faith of the leasing arrangement, the court of appeals said, "But we think this construction of a collective bargaining contract ignores the covenant of good faith and fair dealing which must inhere in every collective bargaining contract if it is to serve its institutional purpose." 65 The court took a similar approach in Local 795, Teamsters Union v. McMaken Transp. $C o .66$ in construing an agreement containing both a no-strike clause and a provision permitting the employees to honor picket lines. While engaged in an organizational campaign to unionize the employer's clerical personnel, the Teamsters Union established a picket line around the employer's establishment. Truckers and loaders, already members of the union, refused to cross the line. The employer sued to enjoin the breach of the no-strike clause. Affirming the lower court's injunction, 67 the court in effect subordinated the clause permitting members of the union to honor picket lines to the no-strike clause. The court's willingness to subordinate the picket-line clause may be read

64273 F.2d 352 (10th Cir. 1959), reversing 169 F. Supp. 107 (D. Utah 1958). The substantive rule announced by this case-is that abandonment of operations in order to avoid unionization is not only an unfair labor practice, but also a breach of contract. Compare Local 600, UAW v. Ford Motor Co., 113 F. Supp. 834 (E.D. Mich. 1953). See Note, 74 HARV. L. REV. 622 (1961).

$65 \mathrm{Id}$. at 356.

66282 F.2d 345 (10th Cir. 1960).

67 The granting of injunctive relief under section 301, of course, presents a conflict with the policy expressed in the Norris-LaGuardia Act. The courts have divided upon the granting of such relief. See Comment, 72 HaRv. L. Rev. 354 (1958); Comment, 25 U. CHI. L. Rev. 496 (1958) (advocating the granting of injunctions despite Norris-LaGuardia). 
as implying a good faith obligation on the union's part not to make its own performance of the no-strike clause impossible. Similarly, in Fruit \& Vegetable Packers Union v. Torvig Sealander Fruit Co., 68 a provision leaving discharges for inefficiency to the discretion of management was read to require the application of fair and reasonable standards. This approach to good faith obligations is not dissimilar to the rules applied in commercial contract cases, and promises to be of particular utility in the labor contract field where agreements frequently fail to spell out in detail the standards applicable to the parties' performance.

Litigation concerning implied substantive terms in collective bargaining agreements has centered around implied no-strike clauses in broadly phrased grievance-arbitration provisions. Several courts have construed clauses referring to "all disputes" or "any grievance" as implying a union promise not to strike without first referring the dispute to the grievance machinery. 69 This construction remains in doubt, since the affirmance of it in the Benedict case 70 was by an equally-divided Court. Where the history of bargaining between the parties indicates that the union did not intend to be so bound, it is difficult to justify the finding of such an implied obligation.71 Although the Warrior case indicates that arbitration is favored by the Supreme Court, Congress has thus far refused to compel arbitration of all disputes. It would seem clearly improper for the courts to accomplish by construction of contracts the same result absent a clear showing of intention to be bound.

\section{BREACH AND TERMINATION}

The typical union breach is a strike in violation of a no-strike clause. The difficult problem here is allocation of responsibility for wildcat strikeswork stoppages not formally instigated by the union charged with contractual responsibility. 72 On the management side, a variety of actual or claimed breaches can arise. Typically, these include refusals to arbitrate disputes, 73

68160 F. Supp. 623 (E.D. Wash. 1958). A similar result was reached in Local 205, Radio \& Mach. Workers Union v. General Elec. Co., 172 F. Supp. 53 (D. Mass. 1959), where the contract failed to lay down any standards applicable to discharges. The court nevertheless implied a requirement of "objective cause" for discharge and ordered arbitration. But see Local 201, Radio \& Mach. Workers Union v. General Elec. Co., 283 F.2d 147 (1st Cir. 1960).

${ }^{69}$ Lewis v. Benedict Coal Corp., 259 F.2d 346 (6th Cir. 1958), aff'd mem., 361 U.S. 459 (1959). Teamsters Union v. W. L. Mead, Inc., 230 F.2d 576 (1st Cir. 1956); Gay's Express, Inc. v. Teamsters Union, 169 F. Supp. 834 (D. Mass. 1959).

70 Lewis v. Benedict Coal Corp., supra note 69.

${ }^{2}$ Cf. UMW v. NLRB, 257 F.2d 211 (D.C. Cir. 1958). However, resort to the grievance machinery arguably could be construed as a condition precedent to a strike.

72 See United Constr. Workers v. Haislip Baking Co., 223 F.2d 827 (4th Cir. 1955); International Molders Union v. Susquehananna Casting Co., 184 F. Supp. 543 (M.D. Pa. 1960).

${ }^{73}$ See Textile Workers Union v. Lincoln Mills, 353 U.S. 448 (1957). 
discharges of individual employees, 74 failures to check off union dues 75 or make pension or welfare fund payments. ${ }^{76}$ Two frequently litigated claims have involved charges that a change in the location of an employer's plant violates the recognition clause in the agreement or charges that a shut down is a lockout. The courts have refused to find breach of the agreement in such cases where the employer's action was justifiable as an exercise of business judgment. The New Park Mining case 77 suggests that the test determinative of this issue is analogous to that employed in employer discrimination cases under the act. 78 Unless the employer's action is motivated by the desire to avoid his contractual obligation to the union, changes in plant location are management functions and not subject to the agreement. 79 However, the parties may contract to prevent such plant relocation and run-away-shop clauses are actionable under section 301.80 Similarly, where an employer is forced to shut down his operation for business reasons, such action is also deemed a management function and not a lockout. 81

Termination of the collective bargaining agreement involves problems peculiar to the labor field because of the statutory duty to bargain imposed upon the parties by the act. Section $8(d)$ of the act imposes a mandatory sixty-day "cooling off" period following notice to modify or terminate an existing agreement. This period was intended to provide a period of peaceful

74 See Radio \& Mach. Workers Union v. General Elec. 231 F.2d 259 (D.C. Cir. 1956)

75 See Local 937, UAW v. Royal Typewriter Co., 88 F. Supp. 669 (D. Conn. 1949).

76 Lewis v. Mears, 168 F. Supp. 134 (N.D. W.Va. 1958).

77273 F.2d 352 (10th Cir. 1959).

78 See, e.g., Diaper Jean Mfg. Co., 109 N.L.R.B. 1045 (1954); Rome Prods., 77 N.L.R.B. 1217 (1948).

79 Local 2040, Int'l Ass'n of Machinists v. Servel, Inc., 268 F.2d 692 (7th Cir. 1959) (dictum); Local 600, UAW v. Ford Motor Co., 173 F. Supp. 834 (E.D. Mich. 1953). But see Newpark Mining Co. v. United Steelworkers of America, 288 F.2d 225 (10th Cir. 1961) (applying an objective test based upon continuity with former operations and company domination of the leasing arrangement).

80 United Shoe Workers v. Brooks Shoe Mfg. Co., 187 F. Supp. 509 (E.D. Pa. 1960).

81 Local 50, Bakery Workers Union v. General Baking Co., 97 F. Supp. 73 (S.D. N.Y. 1951) (shutdown of bakery because of drivers' strike). In Zdanok v. Glidden Co., 185 F. Supp. 441 (S.D.N.Y. 1960), the district court applying New York law in a diversity case held that the shut down of operations at one plant and the transfer of the work to other factories of the employer did not abrogate seniority rights claimed by the employees under the contract by shifting the locus of plant operations. The Court of Appeals for the Second Circuit reversed, 288 F. 2d 99 (2d Cir. 1961), on the ground that the contract indicated no intention of the parties to destroy the structure of rights created by the agreement. The court reached this result despite specific contract language stating that the agreement applied to employees at a specifically identified location. Judge Lombard disented both on the ground that section 301 required the application of federal law to labor contract actions brought under diversity jurisdiction, and that the agreement did not contemplate the continuation of seniority rights for employees following a good faith relocation of the employers operations. See also Metal Polishers Union v. Viking Equip. Co., 278 F.2d 142 (3d Cir. 1960) (reaching the same result as the Glidden case). 
renegotiation, during which neither party can resort to strikes or lockouts. The terms of the collective bargaining agreement may extend the statutory sixty-day interval before the parties may resort to economic weapons. The Supreme Court's decision in NLRB v. Lion Oil Co.82 may be read as invalidating such private restrictions upon the right to strike or lock out. In Lion Oil the union struck more than sixty days after giving notice that it wished to reopen the contract and modify its terms, but did not comply with the agreement's requirement that termination follow sixty days after giving written notice following the end of an initial sixty-day negotiation period. The Court noted both provisions in its opinion and assumed that "at all relevant times a collective bargaining agreement was in effect." 83 Nevertheless, the Court held the strike not violative of section 8 (d), although the majority opinion did not discuss the notice requirement imposed by the contract. Broadly read, the opinion suggests that compliance with the statutory sixty-day period is sufficient, and that strikes after that period are protected by the act. Mr. Justice Frankfurter, concurring in part and dissenting in part, would have affirmed the court below insofar as its decision rested upon the union's failure to comply with the notice of termination requirement imposed by the contract. The Supreme Court's treatment of the problem in Lion Oil is equivocal at best, and the lower courts appear divided. The early Patterson Parchment case, 84 applying state law, held that where an agreement was extended by the parties pending renegotiation of the contract, the no-strike clause was terminated by a strike following a bargaining impasse. However, in International Union of Operating Eng'rs v. Dahlem Constr. Co., 85 the only case squarely presenting the question, the court held that the requirements of section 8(d) were irrelevant where the agreement provided for a cooling-off period exceeding that prescribed by the statute. The court held that the strike was a violation of the agreement because the union failed to give notice of termination, despite the fact that the strike occurred five months after the notice to modify had been given. It should be noted, however, that Dahlem involved a situation clearly distinguishable from Patterson Parchment. In the latter case the extension agreement was reached during current bargaining when an impasse appeared likely. Dahlem, on the other hand, involved the construction of an extension period written into the original agreement. It is considerably more likely that the parties contemplated the application of the no-strike pledge in Dahlem than that the union bargaining in an impasse situation would relinquish the right to employ its economic weapons.

Two conflicting policies must be considered in analyzing the extension

82352 U.S. 282 (1957).

83 Id. at 287.

84 Patterson Parchment Paper Co. v. International Bhd. of Paper Makers, 191 F.2d 252 (3d Cir. 1951).

85193 F.2d 470 (6th Cir. 1951). 
problem. Economic pressure is the mechanism of settlement adopted by the national labor law. Accordingly, private agreements restricting the exercise of such pressure could arguably be considered contrary to public policy. This position was indirectly suggested by Judge Aldridge in a recent district court case 86 involving the arbitrability of a dispute concerning employee discharges. The union argued that all disputes were arbitrable because of the presence of a no-strike clause in the agreement. Judge Aldridge rejected the suggestion that the union would be bound by the no-strike clause where non-arbitrable disputes were involved, but held that the dispute in question was arbitrable. Underlying this view is recognition of the basic relationship between the exercise of economic pressure and the realities of the collective bargaining process. This relationship suggests that as a matter of policy, where a duty to bargain exists, the ability to make bargaining demands effective requires the free exercise of the right to strike. 87 Persuasive as this argument may be, the history of bargaining under the national act has emphasized the parties' freedom to fix the terms of their agreements without government interference.88 Under this view it would be inappropriate for the federal courts to deny enforcement of termination agreements merely because they are more onerous to either party than the obligations imposed by the statute.

Under conventional contract rules material breach of contract excuses further performance by the promisor. The defense of material breach has been asserted in several cases brought against unions for breach of no-strike clauses. In Ludlow Mfg. \& Sales Co. v. Textile Workers Union ${ }^{89}$ the court assumed that a material breach would excuse the union's failure to perform the no-strike agreement, but held that a delay in commencing negotiations following the union's notice to modify the agreement was not a material breach. Under the Mastro Plastics doctrine 90 an employer's antecedent unfair labor practices excuse union non-performance of a no-strike agreement.

86 Local 205, Radio \& Mach. Workers Union v. General Elec. Co., 172 F. Supp. 53 (D. Mass. 1959). The court's cryptic statement can be narrowed to mere construction of the particular agreement.

87 See, e.g., United Steelworkers v. Shakespeare Co., 84 F. Supp. 267 (W.D. Mich. 1949). Of course, management would also have the opportunity to exert pressure upon the union through the employees directly if the contract is treated as terminated. See Mountain States Div. Communications Workers Union 17, v. Mountain States T. \& T. Co., 81 F. Supp. 397 (D. Colo. 1948). The Second Circuit recently held that unilateral changes in the wage rate and conditions of employment during bargaining negotiations are not per se refusals to bargain in good faith. NLRB v. Katz, 47 L.R.R.M. 2967 (2d Cir. 1961).

88 NLRB v. American Nat. Ins. Co., 343 U.S. 395 (1952); White v. NLRB, 255 F.2d 564 (5th Cir. 1958). But see NLRB v. Borg-Warner Corp., 356 U.S. 342 (1958).

s9 108 F. Supp. 45 (D. Del. 1952).

90 Mastro Plastics Corp. v. NLRB, 350 U.S. 270 (1950. But see Resnauer Transp. Co. v. United Marine Div., 112 F. Supp. 940 (S.D.N.Y. 1953). 
In Mid-West Metallic Prods.91 the Board refused to apply the Mastro Plastics rule where the no-strike clause waived the right to strike only prior to the grievance procedure and where the discharge of the employee in question presented an arbitrable dispute. A similar approach was taken in Local $1055, I B E W$ v. Gulf Power Co.,92 where the court refused to mechanically apply the Mastro Plastics rule in a contract action for breach of a no-strike clause. In Gulf Power the union struck after the employer refused to bargain about the status of certain supervisory employees. The company treated the contract as terminated by the strike, and the union brought suit for a declaratory judgment of its rights under the agreement and an injunction ordering the company to comply with terms of the agreement. The company counterclaimed for injunctive relief unspecified in the report. The court held that the union was unjustified in striking over a relatively minor matter where agreement had been reached on other issues involved in the negotiations. Mastro Plastics was distinguished as involving unfair labor practices in the manipulation of the bargaining unit itself, presumably a matter of greater importance to the union.

Because in Gulf Power both parties had breached their agreement-the employer by refusing to bargain, the union by striking-the court applied the "clean hands" doctrine and denied equitable relief to both. Although the court's assumption that the employer's action in refusing to bargain with the union over the status of the supervisory employees was an unfair labor practice is doubtful, its approach to the impact of the alleged unfair labor practice is sensible. Unfair labor practices vary in seriousness, and it would be regrettable to permit a relatively minor or technical breach of a statutory duty to justify complete abrogration of the contract. 93 Consistent with the concept of material breach of contract, the Mastro Plastics defense should be limited to situations where the unfair practice is of substantial magnitude. The wide-spread use of arbitration agreements provides adequate relief for minor breaches of both the contract and the statute. Self-help remedies should be limited where the Board remedies are adquate or arbitration is available.

The courts are in general agreement that an arbitration clause may not be asserted as a defense to a damage action brought for the alleged breach of a no-strike clause. ${ }^{94}$ The rationale of the courts in these cases is that arbitra-

91 Mid-West Metallic Prods., 121 N.L.R.B. 1317 (1958), appeal dismissed sub nom. Lyke v. NLRB, 38 C.C.H. LAB. CAS. ๆ65875 (1958).

92182 F. Supp. 950 (N.D. Fla. 1960).

93 The Board emphasized the flagrant character of the unfair labor practice in Mastro Plastics. Cf. ABA ReP., supra note 50.

94 Teamsters Union v. W. L. Mead, Inc., 230 F.2d 576 (1st Cir. 1956); Lodge 12, IAM v. Cameron Iron Works, 257 F.2d 467 (5th Cir. 1958); International Union United Auto Aircraft v. Benton Harbor Malleable Indus., 242 F.2d 536 (6th Cir. 1957); Gay's Express 
tion is an alternative to settlement of disputes by strike, and that a strike in breach of the agreement is not itself within the scope of the arbitration agreement. It should be noted that all but two of the cases so holding were decided prior to the Supreme Court's rejection of the Cutler-Hammer approach 95 to arbitrability in 1960 . The Court's view that questions of arbitrability are properly for the arbitrator casts doubt upon the validity of these cases. Nevertheless, the Second Circuit in Drake Bakeries, Inc. v. Local 50, Bakery Workers Union, 96 distinguishing its own earlier precedent, adopted the no-defense rationale. Although this approach appears contrary to the Supreme Court's decisions concerning arbitrability, as a matter of contract construction the result is persuasive. It appears unreasonable to assume that breach of the no-strike pledge is itself considered an arbitrable dispute by the parties. The Supreme Court's approach to arbitrability may, moreover, be inapposite where no-strike clauses are involved. Unlike disputes concerning working conditions and the application of the collective bargaining agreement to the plant routine, the primary issue in cases involving breach of no-strike clauses is a legal one, viz., whether the strike is a violation of the written terms of the agreement. Here the necessity for an arbitrator's expertise appears less pressing, and it is not unreasonable to conclude that the court is equally skilled in determining the scope of a no-strike provision. An underlying factor which may explain the courts' reluctance to shift the dispute to arbitration is the fact that the party in breach has itself bypassed the grievance machinery by resorting to the strike weapon. The policy favoring arbitration as a mechanism for peaceful settlement is inapplicable in these cases.

Individual contracts of employment may not be asserted in defense to suits brought by the union under the collective bargaining agreement. In a suit brought by the union to compel arbitration of the reinstatement status

Inc. v. Teamsters Union ,169 F. Supp. 834 (D. Mass. 1959); Cuneo Press v. Kokomo Paper Handler's Union 34, 235 F.2d 108 (7th Cir. 1956); Markel Elec. Prod. v. Radio \& Mach. Workers Union, 202 F.2d 435 (2d Cir. 1953); International Union of Furniture Workers v. Colonial Hardwood Floor Co., 168 F.2d 33 (4th Cir. 1948); Radio \& Mach. Workers Union v. Miller Metal Prods., Inc., 215 F.2d 221 (4th Cir. 1954); Sinclair Ref. Co. v. Atkinson, 48 L.R.R.M. 2045 (7th Cir. 1961). Contra, Signal-Stat. Corp. v. Local 475, Radio \& Mach. Workers Union, 235 F.2d 298 (2d Cir. 1956); Tenney Eng'r, Inc. v. Radio \& Mach. Workers Union, 174 F. Supp. 878 (D. N.J. 1959); Armstrong-Norwalk Rubber Corp. v. Local 283, Rubber Workers Union 167 F. Supp. 817 (D. Conn. 1958).

95 International Ass'n of Machinists v. Cutler-Hammer, 271 App. Div. 917, 6 N.Y.S.2d 317 (1947).

96287 F.2d 155 (2d Cir. 1961). The court distinguished Markel Elec. Prod. v. Radio \& Mach. Workers Union, 202 F.2d 435 (2d Cir. 1953), as involving a broader arbitration clause. The tendency of the courts in this area to distinguish earlier precedents on the facts appears to be a fruitless exercise in semantics. The impact of the Supreme's Court arbitration cases was minimized by the Court of Appeals for the Sixth Circuit in Vulcan-Cincinnati, Inc., 48 L.R.R.M. 2008 (6th Cir. 1961). The court distinguished the Supreme Court decisions as involving grievance arbitrability and adhered to its earlier precedent holding no-strike breaches not arbitrable. 
of female employees taking pregnancy leave, 97 the company asserted defenses based upon the prior bargaining demands of the union and waivers signed by the individuals at the time such leave was taken. Relying upon the rationale of the J.I. Case Lumber decision 98 , where the Supreme Court held that individual contracts of employment were no defense to the statutory duty to bargain, the Court held that the claims presented an arbitrable issue. This result followed from the fact that "Applications for pregnancy leave cannot be used to limit or condition the terms of the collective agreement. ..."99

Illegality of the contract has been asserted as a defense in several cases. In Local 420, Plumbers Union v. Carrier Corp.100 the union brought suit for damages resulting from the employer's failure to perform an agreement allocating certain equipment installation work to the members of the union. Upon the complaint of a rival union also interested in performing the work, the Board had previously held the contract provision unlawful as a violation of section $8(b)(4)(D)$. The court held the contract unenforceable, but its emphasis on the fact that the particular clause sued upon was itself the source of the illegality suggests that other terms of the agreement were severable and enforceable.101 An illegal clause was held not to invalidate the entire agreement in Sidele Fashions, 102 and the failure of the U.A.W. to comply with the non-communist affidavit provisions was early held to provide no basis for refusing to permit the union to bring a damage action. ${ }^{103}$ However, in United Steelworkers v. Knoxville Iron Co. 104 the court refused to enforce check-off provisions of an agreement found violative of the state "right to work" law. Although the issue has not been squarely presented in any case thus far, the decisions indicate that while illegal provisions are not actionable they are severable from the main contract and other provisions remain enforceable. 105

In Lewis v. Benedict Coal Corp. 106 the defense of non-performance of the union's no-strike pledge and set-offs for damages resulting from strikes

97 Maryland Tel. Union v. Chesapeake \& Potomac Tel. Co., 187 F. Supp. 101 (D.C. Md. 1960).

98 J.I. Case Co. v. NLRB, 321 U.S. 332 (1944).

99187 F. Supp. at 109.

100130 F. Supp. 26 (E.D. Pa. 1955).

101 See Teamsters Union v. W.L. Mead Co., 230 F.2d 576 (1st Cir. 1956) (dictum). But see, Local 1055, Electrical Workers Union v. Gulf Power Co., 175 F. Supp. 315 (N.D. Fla. 1959) (ordering arbitration of a withdrawal of supervisory employees from an existing bargaining unit).

102 Philadelphia Dress Joint Bd. v. Sidele Fashions, Inc., 187 F. Supp. 96 (E.D. Pa. 1960). 103 UAW v. Wilson Athletic Goods Mfg. Co., 119 F. Supp. 948 (N.D. I1. 1950).

104162 F. Supp. 366 (E.D. Tenn. 1958).

105 Cf. NLRB v. Rockaway News, 345 U.S. 71 (1952).

106361 U.S. 459 (1960). 
were asserted in a suit by the trustees of the Mine Workers' pension fund for payments due under the National Coal Agreement. The case is of interest not only because of its disposition of the issues involved, but also as an indication of the Supreme Court's approach to traditional contract doctrines as applied to labor contracts. Under conventional contract rules third party claims may be set off where performance by the promisor is conditioned upon performance by the promisee. The Court refused to apply this rule to the payments accruing to the fund under the agreement. The Court assumed that to allow the set-off would deplete the pension fund corpus to the extent of the employer's damages. Pointing out that pension funds involve the rights of employees and their families, the Court concluded that the national policy forbade the assertion of damages for breach of contract in such cases. This result seems correct. Suits for non-payment of pension fund amounts seem inappropriate for the litigation of non-performance claims and strike damages. 107

The Court's approach to the problems presented in the Benedict case indicates that the guiding consideration in 301 litigation is national policy and not strict application of commercial contract rules. In refusing to attribute responsibility to the pension fund trustees for the acts of the union, the Court noted that the policy expressed in section 301(b) of the Act was to limit the responsibility for union action to the union as an entity. This policy was applied by the Court in preference to otherwise relevant contract doctrines.

Relatively few of the cases filed under section 301 have reached final judgment, 108 and as a result the case law dealing with damage questions is inadequate. On the union side damage claims are usually asserted for failure to pay the proper wage rate, or for back pay awards. Estimation of damages in these cases present few difficulties since the wage rate itself provides an objective measure.

Damage suits for breach of no-strike clauses present more challenging problems. In Structural Steel Ass'n v. Shopmen's Local Union 109 the court granted recovery of the employer's average daily overhead costs for the period of work stoppage against a union striking in violation of a no-strike agreement. The court disallowed, however, expenses for travel, entertainment and the company's charitable contributions. A similar approach was taken in Radio \& Mach. Workers Union v. Oliver Corp.110 The court granted recovery of

107 See Note, 49 Geo. L. Rev. 368 (1960).

108 Of 35 cases filed in the District Court for the Northern District of Illinois over a five year period (1956-60) only five reached final judgment. Letter from Mr. Joseph Spaniol, Jr. of the Administrative Office of the United States Courts to the University of Chicago Law Review. Mr. Spaniol finds that his records indicate that the majority of 301 cases in other districts are also dismissed or settled before trial.

109172 F. Supp. 354 (D.N.J. 1959).

110205 F.2d 376 (8th Cir. 1953). 
$471 / 2$ percent of the daily fixed overhead charges where a partial strike reduced production to $521 / 2$ percent of normal output. No case has granted recovery for lost profit, although it seems evident that such damages, if provable, would be considered contemplated by a no-strike agreement. Serious difficulties arise in this area if the conventional mitigation of damages and actual loss rules are applied. The opportunity for an employer to increase production after a strike and the fact that no sales may be lost as a result of a strike could render the right of action for breach of no-strike clauses nugatory in terms of money damages. Particularly where industry-wide strikes are involved, the employer's loss, if any, as a result of the strike is difficult to demonstrate. In Alcoa Steamship Co. v. Comerford"11 a strict mitigation of damages rule was applied. The union demanded the addition of more men to the longshoremen working crews; all but one of the employers complied with the union demand and sued to recover the additional cost of operation incurred by the increase in the work force. Alcoa refused to accede to the union demand, and sued for additional demurrage and operating costs attributable to the union's subsequent strike. Damages in the amount of the additional labor costs were readily granted employers complying with the union demand. Alcoa, however, was denied recovery of its costs on the ground that mitigation of damages required the employer to comply with the union's demand and to sue for recovery of wage costs. This result illustrates the difficulty of applying conventional mitigation of damage rules in this area. Unlike the commercial contract the relationship between the employer and the union is a continuing one. Acceding to union demands clearly violative of the agreement establishes precedents in the working relationship and psychological expectations on the part of the employees that may prove troublesome to the employer in subsequent bargaining. Despite the possibility that damage awards may constitute windfalls to employers, the value of the damage action as a sanction and the serious possibility that employers will be unable to prove real losses, such as permanently lost patronage, suggest the propriety of a non-technical approach to damage questions.

United Shoe Workers v. Brooks Shoe Mfg. Co.,112 decided in 1960, was the first case awarding punitive damages under section 301 . Without giving notice to the union, the employer moved his plant to another town in Pennsylvania in order to avoid paying the union wage scale in Philadelphia. The court awarded the union damages for its loss of dues, computing this sum on the basis of the union's annual dues collection multiplied by an estimated twenty year life expectancy for the company. The twenty-year period selected equalled the length of time the company had already been in existence, and the court concluded that it was not unreasonable to expect an established firm to continue in existence for a similar period. In addition, the court

11117 CCH LAB. CAS. $\uparrow 65480$ (S.D.N.Y. 1949) (unreported).

112187 F. Supp. 509 (E.D. Pa. 1960). 
granted punitive damages in the amount of fifty thousand dollars-nearly double the actual damages awarded. The court refused, however, to order the employer to return his operation to Philadelphia or to reinstate the displaced employees. This approach is similar to that taken by the Board in runaway-shop cases, and apparently rests upon the assumption that to force the employer to return to his previous location would constitute undue hardship. In view of the court's finding that the employer reduced his labor costs by fifteen to twenty percent, the superficially harsh punitive damage award appears not unreasonable. To the extent that the award accrues to the employees through the union such awards may serve as a basis for de facto severance pay. Such punitive awards, however, might well be confined to run-away-shop situations where the parties do not have a continuing bargaining relationship. The award of harsh damages against either unions or employers does not furnish an amicable bargaining and working relationship, although it could be suggested that where a contract breach is so flagrant as to justify such an award little remains of a harmonious atmosphere.

\section{AgENCY RULES}

Problems of agency have arisen in cases involving the liability of parent unions for strikes by local bodies. Where, as is frequently the case in nationally negotiated agreements, the parent international union is a party to the agreement, it is sued as a principal. In Boeing Airplane Co. v. Lodge No. 751, IAM113 the court held that whether the international union was liable in damages for breach of a no-strike agreement was a matter of intention; it ruled that where the local union has the authority to strike without permission from the international and operates with substantial autonomy, the liability of the parent, if any, was several and not joint. The court did not reach the liability question, although it suggested in dictum that the international was not liable, because the employer had elected to terminate the agreement. In permitting evidence to be introduced that the international had signed as a principal in United Packinghouse Workers v. Maurer-Neurer, Inc., ${ }^{114}$ the court suggested a functional test of the parent's responsibility. The court indicated that where the local was merely an administrative unit in a tightly controlled national union engaged in nation-wide bargaining, it would not be inappropriate to hold the parent financially liable for the actions of the local. Joint liability was imposed upon the local and the parent in the Morrison-Knudsen case, 115 where both bodies acted in concert in causing work stoppages of construction projects. An opposite result has been reached

11391 F. Supp. 596 (W.D. Wash. 1950), aff' $d, 188$ F.2d 356 (9th Cir. 1951).

114272 F.2d 647 (10th Cir. 1959).

115270 F.2d 530 (9th Cir. 1959). 
in cases which appear to have involved clear instances of wild-cat strikes.116

Responsibility in these cases properly, and necessarily, turns on the facts of the particular situation. It would be intolerable to hold parent unions responsible for strike action at the local level where the parent does not in fact exercise control over the local's activity. Conversely, where a dominant national union is involved it would be improper to insulate the parent from financial responsibility for its own acts. Although the parent's signatory status with regard to the agreement could be considered analogous to that of a surety guaranteeing performance, such a view, as a rule of law, appears too mechanical. The factual approach of the courts in this area appears to be a sensible response to the realities of existing union organization.

The converse situation-the imposition of contract responsibility upon bogus successor employers-has been less skillfully handled. Two recent cases brought under the United States Arbitration Act illustrate the problem.117 In both, the district court refused to join alleged successor enterprises in suits for arbitration of severance allowance brought under the collective bargaining agreement against the former employer. Although the cases may be correct on their facts, the courts' mechanical disposition of the claims on the ground that the successors were not parties to the agreement is unsatisfactory. Such an approach facilitates the use of run-away-shop devices, leaving hollow corporate shells as the suable entity. Where substantial identity exists between the shareholders of the contracting employer and the successor business, courts should enforce contractual responsibility upon the successor. 118

\section{ARBITRATION}

Litigation under section 301 has frequently involved the problems of arbitration. Much of the law developed in the federal courts concerning the arbitrability of disputes was rendered obsolete by an important trio of decisions rendered by the Supreme Court in 1960.119 Prior to these decisions

116 Garmeada Coal Co. v. UMW, 230 F.2d 945 (6th Cir. 1956); United Constr. Workers v. Haislip Baking Co., 223 F.2d 872 (4th Cir. 1955).

117 Livingston v. Gindoff Textile Corp., 191 F. Supp. 134 (S.D.N.Y. 1961); Office Employees Union v. Ward-Garcia Corp., 190 F. Supp. 448 (S.D.N.Y. 1961). In Gindoff the court was careful to point out that none of the majority shareholders in the predecessor corporation were participants in the new enterprise. Whether this is a question more appropriately submitted to the arbitrator might be argued.

118 Cf. Steel Workers Union v. New Park Mining Co., 273 F.2d 352 (10th Cir. 1959); NLRB v. Lewis, 246 F.2d 886 (9th Cir. 1957). In Pepper \& Potter, Inc. v. Local 977, UAW, 103 F. Supp. 684 (S.D.N.Y. 1952), the court disregarded a disclaimer of representation by the union, and a disavowal of the union by the employees in a damage action brought for non-performance of an existing contract.

119 Steelworkers Union v. American Mfg. Co., 363 U.S. 564 (1960); Steelworkers Union v. Warrior \& Gulf Nav. Co., 363 U.S. 574 (1960); Steelworkers Union v. Enterprise Wheel \& Car Co., 363 U.S. 593 (1960). 
the federal courts had tended to adopt the so-called Cutler-Hammer approach to arbitrability. ${ }^{120}$ In that case the New York court ruled that arbitrability was a matter of contract. Consequently, the court held that the arbitrability of disputes was in the first instance an issue for the court as a question of contract construction. The Supreme Court, while paying lip service to the contractual basis of the duty to arbitrate disputes, 121 conclusively rejected the application of Cutler-Hammer to suits to compel arbitration in the federal courts. The rule of the cases is clear-the allegation that a dispute exists concerning the meaning or application of any of the terms of the collective agreement, provides a sufficient basis for the federal courts to order arbitration. 122

The effect of these cases upon procedural arbitrability remains unsettled. Judge Wyzanski early suggested that compliance with the procedural requirements of arbitration clauses was a matter within the competence of the arbitrator. ${ }^{123}$ Courts following the Cutler-Hammer doctrine were quick to reject this approach, ${ }^{124}$ but the more recent cases have submitted questions of procedural arbitrability to the arbitrator. ${ }^{125}$ It should be noted, however, that compliance with procedural requirements written into a grievance provision are largely a matter of contract construction. Unlike work disputes and other typical arbitration questions, the industrial context is irrelevant to the determination of these issues. The courts' expertise in construing agreements seems to qualify them as the appropriate forum for determining procedural compliance.

The Enterprise Wheel decision indicates that little if any review of arbitra-

120 International Ass'n of Machinists v. Cutler-Hammer, 271 App. Div. 917, 67 N.Y.S.2d 317 (1947); see Note, 10 SYRACUSE L. Rev. 278 (1959), for a review of the federal cases.

121 See Meltzer, The Supreme Court, Arbitrability and Collective Bargaining, 28 U. CHI. L. REv. 464 (1961).

122 But see Portland Web Pressman's Union v. Oregonian Publishing Co., 286 F.2d 4 (9th Cir. 1960) (arbitration denied on ground of lack of justifiable issues).

123 In re Jacobson, 161 F. Supp. 222 (D. Mass. 1958), rev'd and remanded sub nom. Boston Mut. Life Ins. Co. v. Insurance Agents' Union, 258 F.2d 516 (1st Cir. 1958); Couch v. Prescolite Mfg. Corp., 191 F. Supp. 737. (W.D. Ark. 1961).

124 Brass \& Copper Workers Union v. American Brass Co., 172 F. Supp. 465 (E.D. Wis. 1959); International Union of Operating Eng'rs v. Monsanto Chem. Co., 164 F. Supp. 406 (W.D. Ark. 1948).

125 Local 971, UAW v. Bendix-Westinghouse Co., 188 F. Supp. 842 (N.D. Ohio 1960); Philadelphia Dress Joint Bd. v. Sidele Fashions, Inc., 187 F. Supp. 97 (E.D. Pa. 1960). Contra, Vulcan-Cincinnati, Inc. v. United Steelworkers, 173 N.E.2d 709 (1960) (Ohio Ct. App.) (applying federal law). See Comment, 70 YALE L. J. 611 (1961). The writer does not report all of the relevant cases, but discusses the policy considerations involved. 
tion awards 126 will be attempted in the federal courts and that the older common law view barring resubmission of disputes will not be followed.127

\section{CONCLUSION}

The number of cases decided under section 301 is still too few to permit the statement of broad principles of the emerging law. Because the cases arise in factual contexts where the determinative considerations may differ for superficially similar cases, 128 the effect of precedent will not be strong for some time yet. Moreover, internal disagreements remain unsolved. Lower federal courts have reached divergent results, suggesting conflicting judicial attitudes toward enforcement of collective bargaining agreements under section 301.129 The Supreme Court remains itself divided: one camp espouses the development of a specialized industrial contract law; 130 the other places greater emphasis upon conventional contract doctrines. 131 The resolution of this conflict and its impact upon the development of substantive law under section 301 stimulates a continuing interest in litigation under this section.

126 American Brake Shoe Co. v. Local 149, UAW, 285 F.2d 869 (4th Cir. 1961); Howard v. United States Rubber Co., 190 F. Supp. 663 (D. Mass. 1961).

127 Enterprise Wheel \& Car Corp. v. United Steelworkers, 269 F.2d 327 (4th Cir. 1959), aff'd, 363 U.S. 593 (1960); Glendale Mfg. Co. v. Local 520, Garment Workers Union, 283 F.2d 936 (4th Cir. 1960). Contra, Mercury Oil Ref. Co. v. Oil Workers Union, 187 F.2d 980 (10th Cir. 1951).

${ }^{128}$ See, e.g., the discussion of the Patterson Parchment and Dahlem cases in the text at note 84 supra.

${ }^{129}$ See the discussion in text of the diversity of opinion in the lower federal courts concerning such questions as the application of the Westinghouse doctrine, the availability of declaratory relief under 301, and the arbitrability of breaches of no-strike clauses.

${ }^{130}$ See, e.g., Justice Douglas' remarks in Lewis v. Benedict Coal Corp., 361 U.S. 459, 468 (1959), and his statement in United Steelworkers v. Warrior \& Gulf Nav. Co., 363 U.S. 574 (1960), that "The agreement calls into being a new common law-the common law of a particular industry or of a particular plant." Id. at 579 . The view that the collective agreement is sui generis is criticized in Meltzer, supra note 121, at 480 \& n.68.

131 See, e.g., Justice Whittaker's dissent in the Warrior case, supra note 130, at 585, and Justice Frankfurter's dissenting opinion in Benedict, supra note 130. The apparent division on the Court is reviewed in terms of the recent arbitration cases in Gould, The Supreme Court and Labor Arbitration, 12 LAB. L. J. 331 (1961).

\section{LEX LOCI DELICTI OR LEX FORI?-CONFLICT OF LAWS IN WRONGFUL DEATH ACTIONS AND THE KILBERG CASE}

"Few principles of conflict of laws are as well settled as that, in an action to recover for wrongful death, it is the lex loci delicti which is controlling." 1 The law of the place of injury has been almost uniformly held to determine the

1 Annot., Death of Passenger-Law Applicable, 13 A.L.R.2d 650 (1950). See RestateMENT, CONFICT OF LAWS $\S 391-95$ (1934); 11 AM. JUR. Conflict of Laws § 182 (1937); 2 Beale, Conflict of Laws $\$ 391$ (1935); Goodrich, Conflict of Laws $\$ 102$ (3d ed. 1949). 